\title{
Cultura abierta sin horario ni calendario. El museo de las redes sociales
}

\author{
Lourdes Páez Morales | Museo de Bellas Artes de Sevilla \\ URL de la contribución <www.iaph.es/revistaph/index.php/revistaph/article/view/4789>
}

La llegada de las redes sociales a las instituciones culturales, más concretamente a los museos, fue un revulsivo para el cambio de mentalidad en su servicio al público. La ventana abierta al diálogo que requería una escucha activa trastocó los esquemas de estos organismos acostumbrados a ofrecer discursos incontestables de raigambre académica. Con mayor o menor convencimiento de su provecho, las instituciones culturales, en la medida de sus posibilidades, las pusieron en marcha y acabaron viendo que eran más las ventajas que las desventajas de esta nueva parrilla de salida que las ponía a todas ellas -más o menos- en pie de igualdad. Más de una década después sabemos, por experiencia, que cada uno cuenta con los medios que cuenta, pero que el éxito en las redes es, en buena medida, una cuestión de trabajo, horas, ingenio y ganas de hacerse un hueco en este mar inmenso de posibilidades.

En el Museo de Bellas Artes de Sevilla (en lo sucesivo MBASe), desde que iniciamos nuestra andadura en redes sociales -manifiestamente tardía- en 2013, nos marcamos unas reglas claras: utilizar buenas fotos, contar historias de interés, no desatender las preguntas de los seguidores, utilizar un tono formal y riguroso sin desaprovechar la enorme utilidad de los emoticonos, así como ofrecer, frente al discurso académico que venía recibiendo el público hasta ahora, otros discursos alternativos (feminista, ecologista, en pro de la diversidad sexual...). Desde el principio, la buena acogida evidenció que se estaba consiguiendo algo fundamental: cambiar la mirada de las personas hacia la institución, ganando cercanía y transparencia.

En poco tiempo empezamos a hablarle de tú a tú a instituciones de carácter nacional cuyos recursos eran mayores sin duda que los nuestros. Esa es la magia

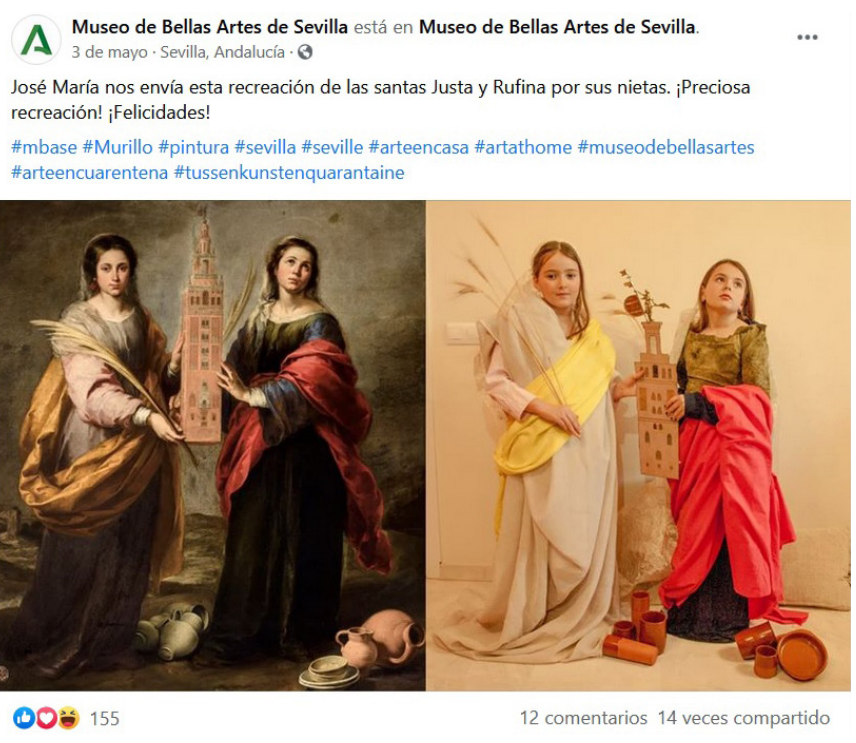

Gracias a las redes sociales los museos se acercan al público y logran crear comunidad | fuente Facebook del Museo de Bellas Artes de Sevilla

de este medio, porque, parafraseando una frase familiar, "desde que se inventaron las redes sociales, no hay museo pequeño". Como ejemplo, la magnífica campaña, que cobró dimensiones internacionales, lanzada por el Museo de Antequera MVCA de "\#cuatrocaras". Sencillamente atractiva, sencillamente brillante.

Decía Bécquer, cuyo retrato nos honra tener en nuestras salas: "El que tiene imaginación, con qué facilidad saca de la nada un mundo". Las redes nos ofrecen la capacidad de brillar -que se lo digan a los microinfluencers-, porque en ellas mostramos nuestra pasión por algo, en nuestro caso el Arte, y creamos comunidad en torno a él.

¿No es grato encontrarte con otras personas a las que te vincula una afición común? En un encuentro internacional en Sevilla en $2017^{1}$, Jasper Visser, experto en trans- 
a debate Comunicación y redes sociales en instituciones culturales

| coordina Candela González Sánchez

formación digital de instituciones culturales, vino a decir que hay personas que pueden llevar en secreto que les gusta, por ejemplo, ABBA, pero que en las redes pierden el pudor de mostrarse tal y como son, porque les dan la maravillosa posibilidad de conectar con más frikis como ellas, teniendo la certeza de que ya no están solas. De eso se trata. De crear comunidad.

Un buen amigo dice con frecuencia: "¡Cómo supo ver Zuckerberg la naturaleza humana!”. Acertó sin duda. En las redes entra en juego el sentimiento, y por ello a veces pasamos del entusiasmo a la decepción o el enfado sin solución de continuidad. El community manager (CM) no debe dejarse llevar por la vehemencia, y ha de calmar los ánimos propios y ajenos con la palabra exacta. Los fuegos son difíciles de apagar ante pasiones tan elevadas como las que suscita el Arte. En torno al MBASe hay un tema siempre candente, por irresoluto sine die: la ampliación. Lleva coleando décadas, y se ha convertido en un tema recurrente para aquellos seguidores que, por el amor que le profesan a esta institución, lo exponen en las redes. Todo el mundo es libre de entrar en el debate, así que, a los argumentos bienintencionados y sopesados de algunas personas, se unen otras argumentaciones algo peregrinas que intentamos rebatir con el mejor de los tonos y las razones que las hacen insostenibles, muchas derivadas del encorsetado modus operandi de la administración, pero que nunca satisfacen a la persona que las tiene enraizadas en su fuero interno. Sin embargo, la escucha activa es la clave para hacer que las redes sean un instrumento útil y que revierta en la mejora del servicio. La opinión del público de redes no debe ser menospreciada como antaño, cuando la administración tenía la única palabra. Conceptos como transparencia o participación ciudadana han llegado para quedarse. La ciudadanía opina y es escuchada. Y su opinión ya no cae en saco roto. En el MBASe tenemos un ejemplo reciente en la exposición de Montañés, maestro de maestros. Cuando de una manera generalizada quienes la habían visitado empezaron a manifestar en las redes la escasa iluminación en una de las piezas clave de la muestra, el Cristo de la Clemencia, motivada por la recreación de su ambiente original, la iluminación se cambió en favor de una mejor apreciación de la obra. Indudablemente la opinión de los usuarios influyó y mucho.

Hasta algo tan aparentemente inamovible como la administración pública está cambiando. La existencia de cursos de formación de community manager ${ }^{2}$ nos da idea de la legitimidad de las redes sociales como un ámbito más donde la administración pública debe estar presente, y de que ese "perfil en construcción" que es el CM está más lejos de ser una isla en medio de un océano de incomprensión.

La desgraciada e inesperada pandemia, una vez más, nos ha hecho creer en las redes sociales. Los museos siguieron "abriendo sus puertas" gracias a ellas. Volviendo a Montañés. Maestro de maestros, a las dos horas de decretarse el cierre de nuestro museo, el pasado 13 de marzo, a solo dos días de la clausura, llevamos a cabo tres conexiones en directo que permitieron visitarla a quienes no habían, ni hubieran podido hacerlo ${ }^{3}$. El aluvión de cariño que recibimos aquel día no tiene precio.

Ya no hay límites. El museo ha dejado de tener horarios y puedes visitarlo desde el rincón más alejado de la Tierra. ¿Gracias a qué? A las redes sociales.

\section{NOTAS}

1. Museos y Educación en la era digital. Facultad de Ciencias de la Educación. Universidad de Sevilla, 2017.

2. La Junta de Andalucía acaba de realizar en 2020 la sexta edición del curso Community Manager para la Administración Pública.

3. https://www.facebook.com/507858365941325/videos/518660972059908; https://www.facebook.com/50 7858365941325/videos/261784764825364; https://www. facebook.com/507858365941325/videos/ 1488080438050937 